\title{
Acute and Subacute Toxicological Studies of Annona Vepretorum in Experimental Animals
}

\section{(ㄷ) (1) (우) $\Theta$}

\author{
Authors \\ Juliane C. Silva1, 2, 3, Tâmara C. Diniz², Érica M. Lavor², Mariana G. Silva², Sarah R.G. Lima-Saraiva², \\ Raimundo G. Oliveira-Junior ${ }^{2}$, Viviane N. Souza², Lívia B.A. Sousa ${ }^{1}$, Rosemairy L. Mendes², Lucindo J. Quintans-Júnior³, \\ Marismar F. Nascimento ${ }^{4}$, Rose N. Pereira-Filho ${ }^{4}$, Ricardo L.C. Albuquerque-Junior ${ }^{4}$, Jackson R.G.S. Almeida ${ }^{2}$
}

\section{Affiliations}

1 Nucleus of Biological Sciences, State University of Health Sciences of Alagoas, Maceió, Alagoas, Brazil

2 Center for Studies and Research of Medicinal Plants, Federal University of San Francisco Valley, Petrolina, Pernambuco, Brazil

3 Department of Physiology, Federal University of Sergipe (DFS/UFS), São Cristóvão, Sergipe, Brazil

4 Laboratory of Morphology and Experimental Pathology, University Tiradentes, Aracaju, Sergipe, Brazil

Key words

Annona vepretorum, annonaceae, natural products, toxicity, acute toxicity, subacute toxicity

$\begin{array}{ll}\text { received } & 31.05 .2018 \\ \text { revised } & 18.12 .2018 \\ \text { accepted } & 08.01 .2019\end{array}$

Bibliography

DOI https://doi.org/10.1055/a-0833-8785

Planta Med Int Open 2019; 6: e15-e22

(c) Georg Thieme Verlag KG Stuttgart · New York

ISSN 2509-9264

\section{Correspondence}

Jackson R. G. S. Almeida

Center for Studies and Research of Medicinal Plants

Federal University of San Francisco Valley

Av. José de Sá Maniçoba

56304-205 Petrolina

Pernambuco

Brazil

Tel.: + 5587988050771, Fax: + 558721016862

jackson.guedes@univasf.edu.br

\section{ABSTRACT}

Annona vepretorum is endemic from the Brazilian Caatinga biome and is used in human nutrition. The present study aimed to investigate the toxic effects of the ethanolic extract from the leaves of this species. The leaves of $A$. vepretorum were collected, dried, pulverized, and macerated with ethanol to yield the crude ethanol extract of $A$. vepretorum. HPLC-diode array detection was used to determine the fingerprint chromatogram of the extract. In toxicity studies, the acute toxicity experimental group was administered a single dose of the ethanol extract of $A$. vepretorum $(1 \mathrm{~g} / \mathrm{kg})$, while in the subacute toxicity experimental group, the ethanol extract of $A$. vepretorum was administered orally, daily for 30 days, at doses of 100 and $400 \mathrm{mg} / \mathrm{kg}$. Death and signs of toxicity were observed and at the end, the animals were anesthetized, and blood and organs were then collected. The presence of the flavonoid rutin in the extract was confirmed using HPLC-diode array detection. In the evaluation of acute and subacute toxicity, there were no behavioral and physiological changes or signs of toxicity, and no occurrences of mice deaths were registered. The organs had normal color and preserved architecture, and no statistical variations in weight were observed. The results of the hematological and biochemical parameters after the administration of the ethanol extract of $A$. vepretorum showed no significant change, except in the count of the number of leukocytes and triglycerides. The histopathologic analysis of the liver, kidneys, and stomach indicated architecture with normal aspects. Thus, the toxicity study indicates low toxicity of the ethanol extract of $A$. vepretorum. Such information will be helpful in future clinical studies. 


\section{Introduction}

Annona vepretorum Mart., popularly known as "pinha-da-caatinga”, belongs to the Annonaceae family and is endemic from the Brazilian Caatinga biome [1]. This species is widely used in human nutrition and its fruits are consumed in natura or in the form of juices [2]. Its roots, when macerated, have a popular indication for bee stings and snake bites, as well as pain and inflammatory conditions. A leaf decoction is popularly used as a bath for allergies, skin diseases, yeast, and bacterial infections [3].

Phytochemical studies with the ethanol extract from $A$. vepretorum leaves revealed the presence of a variety of chemical constituents such as phenols, flavonoids, steroids, and terpenoids, which can be responsible for its pharmacological activities. The ethanolic extract has a sedative effect that does not affect the motor coordination of the mice. Anti-inflammatory and antinociceptive activities have also been reported, which are probably related to the activation of opioid receptors and the inhibition of the release of mediators of the inflammatory process. This extract also demonstrates antioxidant, cytotoxic, and antimicrobial activities [4-7].

Despite its use as food and in popular medicine, as well as the chemical and pharmacological potential, toxicity information on $A$. vepretorum is scarce. Thus, the present study aimed to investigate the toxic effects of the ethanolic extract of this plant's etha-

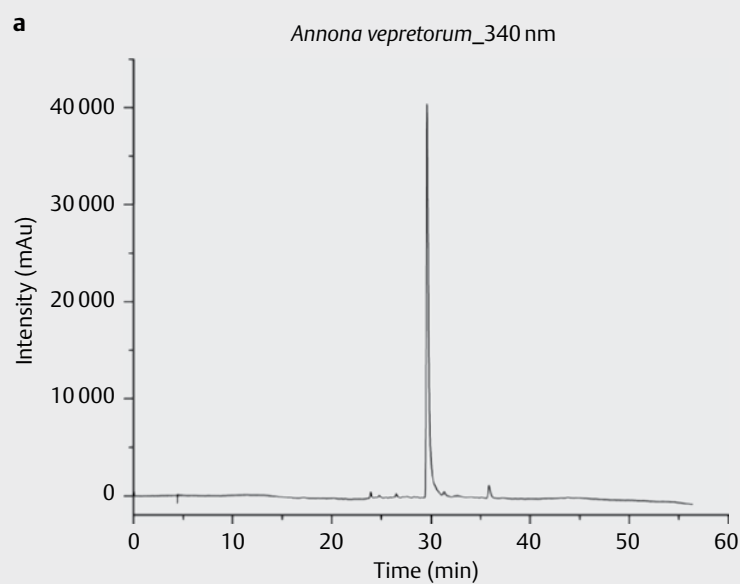

b

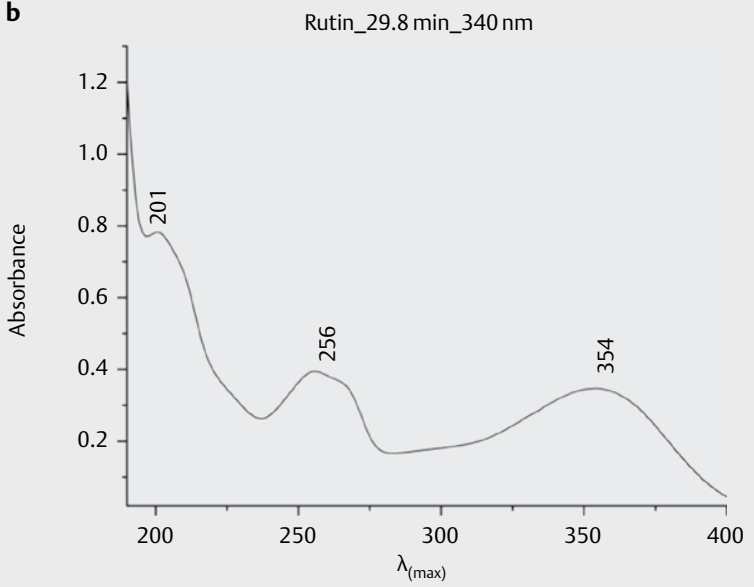

Fig. 1 Chromatogram of $A$. vepretorum ethanolic extract $(340 \mathrm{~nm})$. nolic leaf extract after single and repeated (30-day) oral administration in Swiss albino mice.

\section{Results}

In this study, an HPLC-diode array detection (DAD) method to identify the phenolic profile of the crude ethanolic extract of $A$. vepretorum was performed ( $>$ Fig. 1). By analyzing the chromatographic profile of the extract, one can observe the presence of a major compound at retention time $29.82 \mathrm{~min}$, which showed an absorption spectrum $\lambda$ 201-256-354 ( Fig. 1). This compound was identified as the flavonoid rutin.

In the evaluation of acute toxicity, there were no behavioral or physiological changes or signs of toxicity [8], and no occurrences of death in the mice were registered up to $1 \mathrm{~g} / \mathrm{kg}$ in the first $24 \mathrm{~h}$ after treatment, indicating the absence of toxicity of the extract tested $(1 \mathrm{~g} / \mathrm{kg}$ orally). Consequently, it was not possible to determine the lethal dose, $50 \%\left(L_{50}\right)$. No significant changes were seen in the body weight of the mice group treated with the extract at a dose of $1 \mathrm{~g} / \mathrm{kg}$ or the control group from day 1 to day 14 . At the end of the experiment, the average of body weight of the control group was $37.00 \pm 0.42 \mathrm{~g}$, while that of the group treated with Av-EtOH was $37.78 \pm 0.49 \mathrm{~g}$.

The results of the hematological parameters after administration of $1 \mathrm{~g} / \mathrm{kg}$ of Av-EtOH showed no significant changes, except in counting the number of leukocytes. However, the clinical significance of this increase is being investigated. The results are shown in $>$ Table 1.

The biochemical parameters ( $\triangleright$ Table 2 ) showed no significant differences from the control group and the group treated with $1 \mathrm{~g} /$ $\mathrm{kg} \mathrm{Av}-\mathrm{EtOH}$, indicating that the treatment with the extract did not present side effects in the usual markers of the liver (ALT/AST) and kidneys (creatinine and urea).

The organs had normal color and preserved architecture, and no statistical variations in weight were observed, as can be seen in - Table 3.

- Table 1 Hematological parameters of blood in Swiss mice treated orally with $1.0 \mathrm{~g} / \mathrm{kg}$ of crude ethanol extract of $A$. vepretorum after 14 days (acute toxicity).

\begin{tabular}{|l|c|c|}
\hline \multirow{2}{*}{ Parameters } & \multicolumn{2}{|c|}{ Groups } \\
\cline { 2 - 3 } & Control & After 1 g/kg v.o. \\
\hline Erythrocytes $\left(10^{6} / \mathrm{mm}^{3}\right)$ & $7.92 \pm 0.13$ & $8.34 \pm 0.47$ \\
\hline Hemoglobin $(\mathrm{g} / \mathrm{dL})$ & $12.88 \pm 0.28$ & $13.47 \pm 0.74$ \\
\hline Hematocrit $(\%)$ & $35.06 \pm 0.79$ & $37.42 \pm 2.06$ \\
\hline $\mathrm{MCV}\left(\mu^{3}\right)$ & $44.20 \pm 0.44$ & $44.90 \pm 0.67$ \\
\hline $\mathrm{MCH}(\mu \mathrm{g})$ & $16.24 \pm 0.16$ & $16.17 \pm 0.22$ \\
\hline $\mathrm{MCHC}(\%)$ & $36.13 \pm 0.64$ & $36.00 \pm 0.19$ \\
\hline Leukocytes $\left(10^{3} / \mathrm{mm}^{3}\right)$ & $5.45 \pm 0.52$ & $10.57 \pm 1.75^{*}$ \\
\hline Lymphocites $(\%)$ & $85.20 \pm 2.07$ & $85.50 \pm 1.88$ \\
\hline Neutrophils $(\%)$ & $12.50 \pm 2.00$ & $12.40 \pm 1.60$ \\
\hline Monocytes $(\%)$ & $0.60 \pm 0.30$ & $0.50 \pm 0.26$ \\
\hline Eosinophils $(\%)$ & $1.70 \pm 0.44$ & $1.40 \pm 0.37$ \\
\hline Platelets $\left(10^{3} / \mathrm{mm}^{3}\right)$ & $521.80 \pm 51.42$ & $704.20 \pm 108.40$ \\
\hline \multicolumn{2}{|l|}{ Values are the mean \pm S.E.M, $\mathrm{n}=10 .{ }^{*} \mathrm{P}<0.05 ;$ Student's t-test at $5 \%$} \\
probability & & \\
\hline
\end{tabular}


- Table 2 Biochemical parameters obtained from the serum of Swiss mice treated orally with $1.0 \mathrm{~g} / \mathrm{kg}$ of crude ethanol extract of $A$. vepretorum after 14 days (acute toxicity).

\begin{tabular}{|l|c|c|}
\hline \multirow{2}{*}{ Parameters } & \multicolumn{2}{|c|}{ Groups } \\
\cline { 2 - 3 } & Control & $\mathbf{1 ~ g / k g ~ v . o . ~}$ \\
\hline Glucose $(\mathrm{mg} / \mathrm{dL})$ & $232.00 \pm 16.43$ & $224.20 \pm 10.46$ \\
\hline Cholesterol $(\mathrm{mg} / \mathrm{dL})$ & $75.40 \pm 4.63$ & $75.44 \pm 7.87$ \\
\hline Triglycerides $(\mathrm{mg} / \mathrm{dL})$ & $184.80 \pm 16.76$ & $171.50 \pm 23.77$ \\
\hline AST/GOT $(\mathrm{U} / \mathrm{L})$ & $181.90 \pm 26.06$ & $193.10 \pm 41.82$ \\
\hline ALT/GPT $(\mathrm{U} / \mathrm{L})$ & $56.28 \pm 11.54$ & $60.38 \pm 13.11$ \\
\hline Urea $(\mathrm{mg} / \mathrm{dL})$ & $53.30 \pm 3.41$ & $62.40 \pm 10.54$ \\
\hline Creatinine $(\mathrm{mg} / \mathrm{dL})$ & $0.83 \pm 0.39$ & $0.50 \pm 0.12$ \\
\hline \multicolumn{2}{|l}{ Values are the mean \pm S.E.M, $\mathrm{n}=10$. Student's t-test at 5\% probability } \\
\hline
\end{tabular}

- Table 3 Organ weight of Swiss mice treated orally with $1 \mathrm{~g} / \mathrm{kg}$ of crude ethanol extract of $A$. vepretorum after 14 days (acute toxicity).

\begin{tabular}{|l|c|c|}
\hline \multirow{2}{*}{ Parameters } & \multicolumn{2}{|c|}{ Groups } \\
\cline { 2 - 3 } & Control & $\mathbf{1 ~ g / k g ~ v . o .}$ \\
\hline Heart $(\mathrm{g})$ & $0.17 \pm 0.04$ & $0.17 \pm 0.03$ \\
\hline Lung $(\mathrm{g})$ & $0.28 \pm 0.06$ & $0.27 \pm 0.14$ \\
\hline Liver $(\mathrm{g})$ & $1.64 \pm 0.47$ & $1.68 \pm 0.40$ \\
\hline Stomach $(\mathrm{g})$ & $0.44 \pm 0.12$ & $0.51 \pm 0.10$ \\
\hline Kidney $(\mathrm{g})$ & $0.42 \pm 0.01$ & $0.44 \pm 0.11$ \\
\hline Spleen $(\mathrm{g})$ & $0.11 \pm 0.04$ & $0.10 \pm 0.07$ \\
\hline Pancreas $(\mathrm{g})$ & $0.22 \pm 0.04$ & $0.25 \pm 0.42$ \\
\hline Ovary $(\mathrm{g})$ & $0.02 \pm 0.00$ & $0.02 \pm 0.00$ \\
\hline Testicle $(\mathrm{g})$ & $0.02 \pm 0.00$ & $0.03 \pm 0.00$ \\
\hline
\end{tabular}

Values are mean \pm S.E.M, $n=10$. No statistical variations were observed. Student's t-test at $5 \%$ probability

- Table 4 Hematological parameters of blood in Swiss mice treated orally with $100 \mathrm{mg} / \mathrm{kg}$ and $400 \mathrm{mg} / \mathrm{kg}$ of crude ethanol extract of $A$. vepretorum after 30 days (subchronic toxicity).

\begin{tabular}{|c|c|c|c|}
\hline \multirow{2}{*}{ Parameters } & \multicolumn{3}{|c|}{ Groups } \\
\hline & Control & $100 \mathrm{mg} / \mathrm{kg}$ & $400 \mathrm{mg} / \mathrm{kg}$ \\
\hline Erythrocytes $\left(10^{6} / \mathrm{mm}^{3}\right)$ & $8.72 \pm 0.17$ & $8.66 \pm 0.16$ & $9.03 \pm 0.15$ \\
\hline Hemoglobin (g/dL) & $13.93 \pm 0.23$ & $13.68 \pm 0.35$ & $13.98 \pm 0.20$ \\
\hline Hematocrit (\%) & $41.90 \pm 0.71$ & $41.55 \pm 1.20$ & $41.94 \pm 0.80$ \\
\hline $\operatorname{MCV}\left(\mu^{3}\right)$ & $48.00 \pm 0.26$ & $47.80 \pm 0.72$ & $46.40 \pm 0.30^{*}$ \\
\hline $\mathrm{MCH}(\mu \mathrm{g})$ & $15.99 \pm 0.17$ & $15.77 \pm 0.19$ & $15.50 \pm 0.14^{*}$ \\
\hline $\mathrm{MCHC}(\%)$ & $33.23 \pm 0.30$ & $32.96 \pm 0.26$ & $33.47 \pm 0.31$ \\
\hline Basophils (\%) & $40.00 \pm 0.40$ & $38.64 \pm 0.24$ & $35.13 \pm 0.24$ \\
\hline Eosinophils (\%) & $0.26 \pm 0.10$ & $0.84 \pm 0.33$ & $0.30 \pm 0.09$ \\
\hline Leukocytes $\left(10^{3} / \mathrm{mm}^{3}\right)$ & $4.88 \pm 1.02$ & $6.86 \pm 1.09$ & $6.92 \pm 0.92$ \\
\hline Lymphocites (\%) & $82.55 \pm 2.23$ & $82.10 \pm 0.88$ & $84.24 \pm 1.00$ \\
\hline Monocytes (\%) & $2.70 \pm 0.48$ & $4.43 \pm 0.51$ & $3.42 \pm 0.46$ \\
\hline Neutrophils (\%) & $14.10 \pm 2.09$ & $12.17 \pm 0.60$ & $11.61 \pm 0.73$ \\
\hline Platelets $\left(10^{3} / \mathrm{mm}^{3}\right)$ & $569.30 \pm 41.57$ & $608.70 \pm 32.90$ & $562.60 \pm 30.78$ \\
\hline
\end{tabular}

- Table 5 Biochemical parameters obtained from the serum of Swiss mice treated orally with $100 \mathrm{mg} / \mathrm{kg}$ and $400 \mathrm{mg} / \mathrm{kg}$ of crude ethanol extract of $A$. vepretorum after 30 days (subchronic toxicity).

\begin{tabular}{|c|c|c|c|}
\hline \multirow{2}{*}{ Parameters } & \multicolumn{3}{|c|}{ Groups } \\
\hline & Control & $100 \mathrm{mg} / \mathrm{kg}$ & $400 \mathrm{mg} / \mathrm{kg}$ \\
\hline Glucose (mg/dL) & $198.30 \pm 11.21$ & $193.30 \pm 11.11$ & $173.00 \pm 10.39$ \\
\hline Cholesterol (mg/dL) & $93.13 \pm 5.16$ & $87.50 \pm 3.66$ & $112.60 \pm 20.27$ \\
\hline Triglycerides (mg/dL) & $177.50 \pm 9.25$ & $189.80 \pm 8.51$ & $268.40 \pm 33.34^{*}$ \\
\hline AST/GOT (U/L) & $136.10 \pm 76.71$ & $197.00 \pm 22.07$ & $178.70 \pm 32.42$ \\
\hline ALT/GPT (U/L) & $49.98 \pm 10.14$ & $58.26 \pm 14.66$ & $88.08 \pm 33.37$ \\
\hline Albumine (g/dL) & $2.55 \pm 0.36$ & $2.23 \pm 0.06$ & $2.27 \pm 0.22$ \\
\hline Urea (mg/dL) & $60.25 \pm 2.63$ & $58.20 \pm 2.44$ & $55.30 \pm 5.49$ \\
\hline Creatinine $(\mathrm{mg} / \mathrm{dL})$ & $0.96 \pm 0.10$ & $1.39 \pm 0.37$ & $1.03 \pm 0.28$ \\
\hline \multicolumn{4}{|c|}{$\begin{array}{l}\text { Values are the mean } \pm \text { S.E.M, } n=10 .{ }^{*} P<0.05 \text {; Student's t-test at } 5 \% \\
\text { probability }\end{array}$} \\
\hline
\end{tabular}

The administration of Av-EtOH at doses of 100 and $400 \mathrm{mg} / \mathrm{kg}$ orally for 30 days of treatment did not result in deaths, indicating the absence of toxicity of the extract in the analyzed parameters. Regarding body weight and the consumption of water and food, there was no statistical difference when compared to the control group (data not shown). Moreover, no lethality was recorded for any dose up to the maximum of $400 \mathrm{mg} / \mathrm{kg}$ during the 30 days of treatment.

In the behavioral assessment, piloerection was observed, as well as intense movement of the vibrissae, decreased response to touch, forced breathing, and decreased grip strength at a dose of $400 \mathrm{mg} /$ $\mathrm{kg}$ after 7 days of treatment. However, these behaviors were not observed in the other groups.

For the hematological parameters, the administration of $100 \mathrm{mg} / \mathrm{kg}$ and $400 \mathrm{mg} / \mathrm{kg}$ of $\mathrm{Av}$-EtOH did not indicate a statistically significant difference in these parameters (

The biochemical parameters indicated no significant differences between the control group and the experimental group at a dose of $100 \mathrm{mg} / \mathrm{kg} \mathrm{Av}$-EtOH. The group of $400 \mathrm{mg} / \mathrm{kg} A v$-EtOH presented increased levels only in the values of triglycerides $(p<0.05)$. The results are presented in $>$ Table 5 .

The treatment for 30 days with the extract did not cause significant changes in the weight of the organs analyzed ( $\triangleright$ Table 6 ) or in the macroscopic characteristics.

The histopathological analysis of the liver of the control groups and individuals treated with 100 and $400 \mathrm{mg} / \mathrm{kg} \mathrm{Av}$-EtOH indicated hepatic architecture with normal aspects ( $\triangleright$ Fig. 2 ). The tissue presented cords of regular hepatocytes, limiting sinusoids, sometimes filled by rare red blood cells. The centrilobular veins were slightly dilated and the portal showed dilated vessels (veins and hepatic arteries), supported by loose fibrous connective tissue. Small perivascular and intralobular lymphoid plaques, with no visible reactive activity, were observed. In general, the groups presented hepatocytes with polygonal morphology and granular cytoplasm, sometimes vacuolated (cytoplasmic hydropic vacuolization), and presented mono-, di- or, more rarely, trinucleated hepatocytes with dispersed and granular chromatin. Mitotic figures and apoptotic bodies were found to be uncommon. Thus, it was possible to infer that the treatment with $\mathrm{Av}$-EtOH did not present signs suggestive 
of hepatic toxicity, since the tissue fragments analyzed presented preserved morphology, corroborating the biochemical analyses of hepatic transaminases (GOT and GPT) that did not indicate variations between the groups treated with the extract at doses of 100 and $400 \mathrm{mg} / \mathrm{kg}$ and the control group.

The microscopic analysis of the kidneys ( $\vee$ Fig. 3 ) of the animals submitted to treatments with saline and the extract indicated a distribution of homogeneous renal glomerulus and preserved morphological architecture in the cortical zone with maintenance of the Bowman space. The proximal and distal convoluted tubules were well formed, with no apparent signs of degenerative, inflam-

- Table 6 Organ weight of Swiss mice treated orally with $100 \mathrm{mg} / \mathrm{kg}$ and $400 \mathrm{mg} / \mathrm{kg}$ of crude ethanol extract of $A$. vepretorum after 30 days (subchronic toxicity).

\begin{tabular}{|c|c|c|c|}
\hline \multirow{2}{*}{ Parameters } & \multicolumn{3}{|c|}{ Groups } \\
\hline & Control & After $100 \mathrm{mg} / \mathrm{kg}$ & After $400 \mathrm{mg} / \mathrm{kg}$ \\
\hline Heart (g) & $0.14 \pm 0.01$ & $0.13 \pm 0.00$ & $0.14 \pm 0.01$ \\
\hline Lung (g) & $0.19 \pm 0.01$ & $0.19 \pm 0.00$ & $0.24 \pm 0.03$ \\
\hline Liver (g) & $1.36 \pm 0.10$ & $1.41 \pm 0.06$ & $1.44 \pm 0.06$ \\
\hline Stomach (g) & $0.45 \pm 0.03$ & $0.42 \pm 0.04$ & $0.44 \pm 0.03$ \\
\hline Kidney (g) & $0.30 \pm 0.02$ & $0.37 \pm 0.02$ & $0.35 \pm 0.02$ \\
\hline Spleen (g) & $0.10 \pm 0.00$ & $0.11 \pm 0.01$ & $0.10 \pm 0.00$ \\
\hline Pancreas (g) & $0.16 \pm 0.01$ & $0.19 \pm 0.01$ & $0.21 \pm 0.01$ \\
\hline Ovary (g) & $0.03 \pm 0.00$ & $0.06 \pm 0.02$ & $0.01 \pm 0.00$ \\
\hline Testicle (g) & $0.13 \pm 0.02$ & $0.16 \pm 0.00$ & $0.17 \pm 0.01$ \\
\hline \multicolumn{4}{|c|}{$\begin{array}{l}\text { Values are mean } \pm \text { S.E.M, } n=10 \text {. No statistical variations were } \\
\text { observed. Student's t-test at } 5 \% \text { probability }\end{array}$} \\
\hline
\end{tabular}

matory, or necrotic changes. The medullary layer did not present expressive morphoarchitectural or cytopathological alterations. Thus, the treatment with Av-EtOH did not cause renal toxicity, and this morphological analysis is consistent with serum creatinine and urea levels, which presented normal values.

Histopathological analysis of the stomach indicated that the architecture of this organ was preserved, with gastric crypts presenting a normal structure, and the presence of parietal and zymogenic cells in the tissue. Discrete regions of hyperemia were observed in the mucosal layer, sometimes presenting foci of inflammatory infiltrates, as shown in > Fig. 4.

\section{Discussion}

Although the use of medicinal plants for the treatment of several diseases is widespread, little is known about toxicity and safety [9]. In order to determine the safety of medicinal products and plant products for human use, a toxicological evaluation is performed in several experimental models to predict toxicity and provide guidelines for selecting a safe dose.

Tests that assess acute toxicity are used to classify and appropriately label substances according to their potential toxicity or lethality as established by legislation [10]. The greater general agreement of toxicity in animals and humans is hematological, gastrointestinal, and cardiovascular changes [11]. They give information on organ toxicity and are projected to identify adverse effect levels [12].

The current study evaluated the acute and subacute toxicity profile of $A$. vepretorum. $\mathrm{LD}_{50}$ was not used in this work and was re-

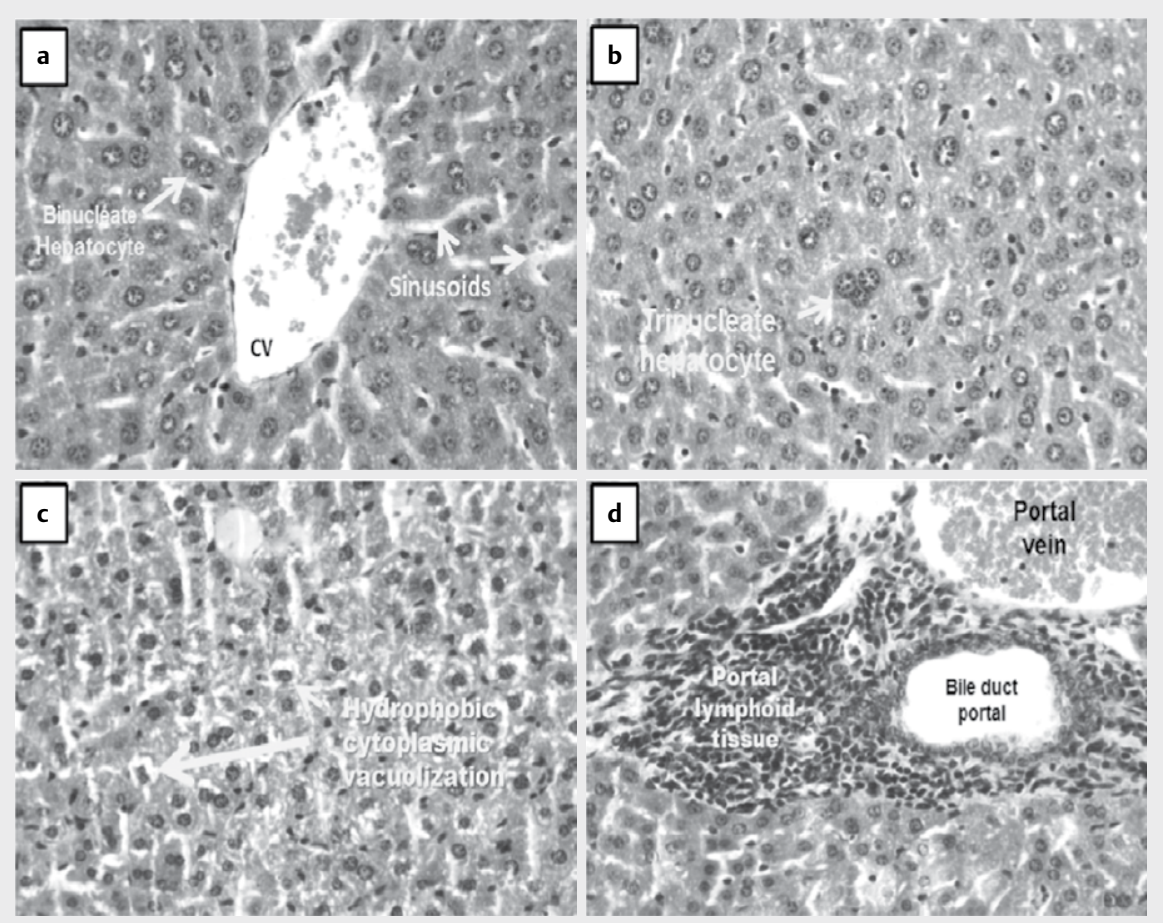

- Fig. 2 Histopathological representation of the livers of mice submitted to the treatment for 30 days with saline $0.9 \%$ and Av-EtOH ( 100 and $400 \mathrm{mg} / \mathrm{kg}) . \mathrm{CV}=$ Centrolobular vein. $\mathbf{a}$ and b $1000 \times, \mathbf{c}$ and $\mathbf{d ~} 400 \times$. 

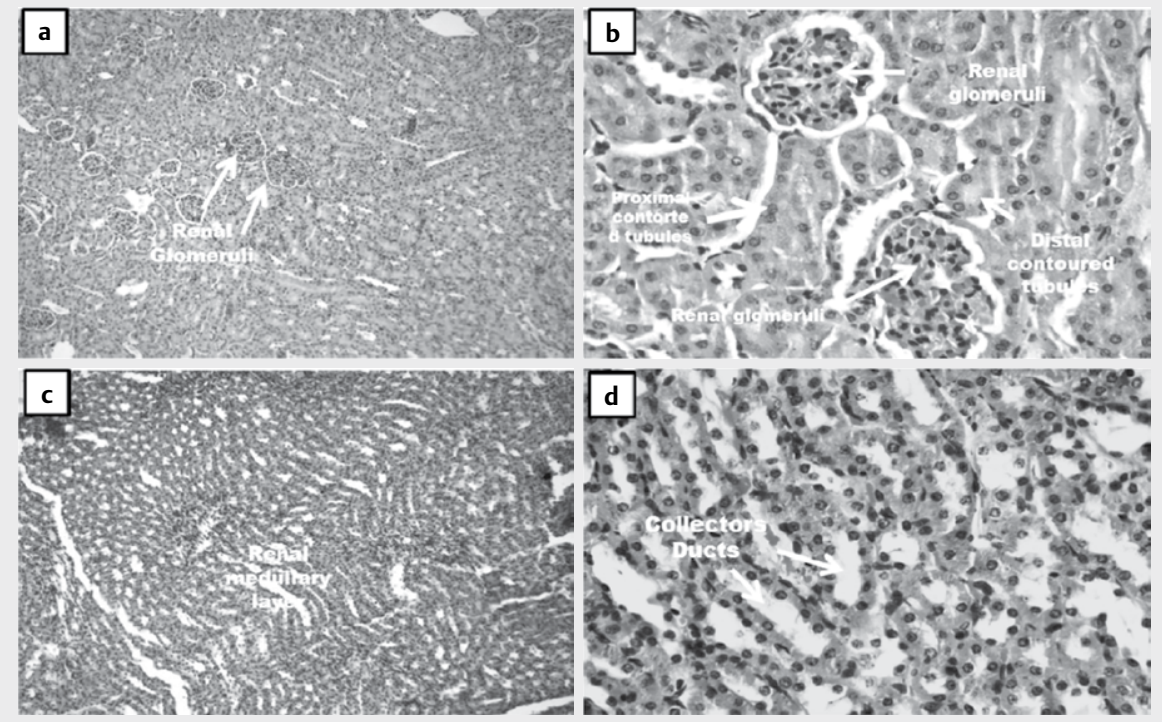

- Fig. 3 Histopathological representation of the kidneys of mice submitted to the treatment for 30 days with saline $0.9 \%$ and Av-EtOH ( 100 and $400 \mathrm{mg} / \mathrm{kg}$ ). a and c $100 \times$, b and $\mathbf{d} 400 \times$.

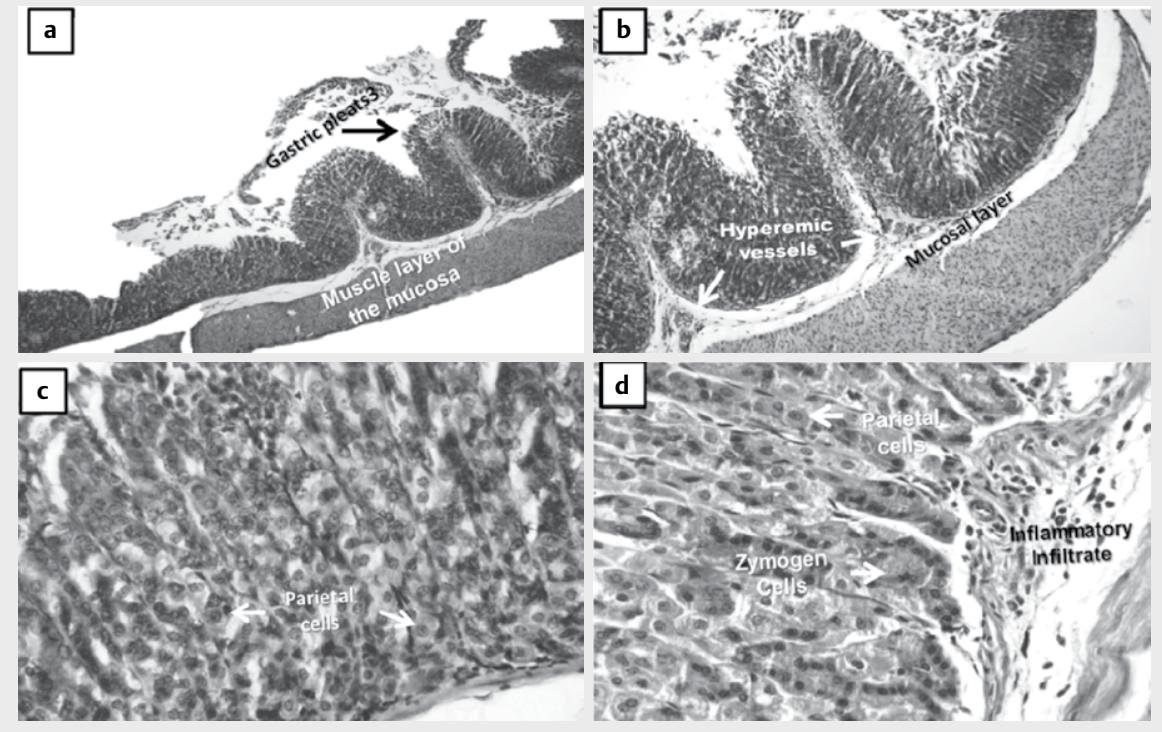

- Fig. 4 Histopathological representation of the stomachs of mice submitted to the treatment for 30 days with saline $0.9 \%$ and $\mathrm{Av}$-EtOH ( 100 and $400 \mathrm{mg} / \mathrm{kg}$ ). a and c $100 \times$, b and d $400 \times$.

placed by the test dose setting, in which the substance to be tested is administered in a specific dosage [8]. Thus, in acute toxicity, we examined the dose of $1 \mathrm{~g} / \mathrm{kg}$ v.o. The Av-EtOH dose is 10 times higher than the dose used in behavioral testing [13].

In the acute study, a single administration of the ethanolic extract at the dose of $1000 \mathrm{mg} / \mathrm{kg}$ had no significant changes in animal behavior and no physiological changes, nor did it display any toxicity signals related to the treatment during the experimental period and did not induce mortality.
In subacute toxicity, the present study showed that the crude ethanolic extract of $A$. vepretorum administered orally at a dose of $100 \mathrm{mg} / \mathrm{kg}$ for 30 days showed no signs of toxicity in the animals, whereas at $400 \mathrm{mg} / \mathrm{kg}$, there were slight changes in behavior in the hematological and biochemical parameters. Both doses did not cause deaths after 30 days of treatment, indicating low toxicity of the extract in the analyzed parameters.

Since changes in body weight have been used as an indicator of adverse effects of drugs and chemicals on laboratory animals [14-17], during acute and subacute toxicity, the animals were observed for 
water and food consumption and body weight. In addition, no significant difference was observed in body weight and food consumption of animals in the treated groups compared with the vehicle control group, indicating that Av-EtOH had no effect on body weight gain and food intake.

In toxicity studies, the effects on behavior, such as aggressiveness, increased ambulation, abdominal contortions, convulsions, stereotypy, intense movement of the vibrissae, piloerection, defecation, paralysis of the front paws, tremors, catatonia, palpebral ptosis, decreased touch response, and sedation, are possible signs of toxicity [8]. In subacute toxicity, piloerection, intense movement of the vibrissae, decreased touch response, forced breathing and decreased grip strength were observed in the treated groups, behaviors not observed in the control group.

The hematopoietic system is one of the most sensitive systems for toxicity in humans and animals, particularly those with mutagenic or cytotoxic potential, resulting in qualitative or quantitative, or transient or permanent changes that may limit the use of drugs, being important allies to the study of toxicity $[13,18]$.

Analysis of blood parameters is relevant for the risk evaluation as the changes in the hematological system have a higher predictive value for human toxicity when the data are translated from animal studies. In the acute toxicity study, with the exception of a small increase in leukocytes, there were no significant alterations in the hematological parameters of mice.

In subacute toxicity, we observed that the results of the hematological parameters (erythrocytes, hemoglobin, hematocrit, CHCM, basophils, eosinophils, leukocytes, lymphocytes, monocytes, neutrophils, and platelets) following Av-EtOH administration did not show significant variation, except in the mean corpuscular volume and corpuscular hemoglobin, which presented a statistical difference, however, without clinical correlation.

Biochemical parameters are also important because they allow for the evaluation of all organs and the general condition of the animal body, especially regarding renal and hepatic functions [19]. In acute toxicity, parameters of biochemical analysis showed no significant differences in relation to the control group. The indicators of liver and kidney function levels of creatinine, urea, transaminases (ALT, AST), and cholesterol were unaffected.

Regarding the biochemical parameters in subacute toxicity, the results did not show significant differences in relation to the control group and the experimental groups. Only a change in triglyceride values $(p<0.05)$ when treated with $400 \mathrm{mg} / \mathrm{kg}$ of $\mathrm{Av}$-EtOH has been observed.

In this study, the usual markers of liver and kidney toxicity were not statistically significant in the treated groups. These parameters are important, since high ALT and AST results in blood indicate changes in liver function, with serum ALT concentration being the first sign of liver injury [20]. Creatinine is known as a good indicator of renal function and its increase means that there is damage in the nephrons [21].

In the macroscopic analysis of the organs, only one animal treated with Av-EtOH presented a lung with a paler and stiffer appearance. There was no significant difference in the weights of the organs when compared to the control group.

The histopathological analysis of this indicates that treatment with Av-EtOH does not present hepatic and renal toxicity, since the architecture of these organs remained unchanged after the treatment with repeated doses of the extract, thus corroborating the laboratory findings in the dosages of AST, ALT, urea, and creatinine ( Table 5), demonstrating a good safety profile of the extract at the doses tested. Toxicological studies indicated that treatment with the extract of the shells of Annona senegalensis Pers. orally for 14 days at doses of 50,100 , and $400 \mathrm{mg} / \mathrm{kg}$ promoted changes in the hepatic architecture of mice only in the treated group at the dose of $400 \mathrm{mg} / \mathrm{kg}$ [22], since the livers showed focal areas of necrosis surrounded by regions of inflammatory infiltrates. Microscopic findings in the stomach tissue ( $>$ Fig. 4) may be related to oral administration of the extract on repeated days; however, the findings are not sufficient to indicate treatment toxicity in this organ, since hyperemia and inflammatory infiltrates have occurred discretely and were not sufficient to alter the tissue architecture.

In conclusion, the present investigation provides valuable information on the acute and subacute toxicity profiles of oral use of the ethanolic extract of $A$. vepretorum. The toxicity study indicates low toxicity of $A$. vepretorum crude ethanolic extract in the analyzed parameters. This information will help future clinical studies on medicinal safety and in vivo experimental studies on the pharmacological potentialities of this mode of administration of plant medicine.

\section{Materials and Methods}

\section{Plant material}

The leaves of $A$. vepretorum were collected in the city of Petrolina (Coordinates: 09¹9'37,50” s; 40¹9'12” W) State of Pernambuco, Brazil, in March 2012. A sample was identified by R. Mello Silva, botanist at the Centro de Referência para Recuperação de Áreas Degradadas (CRAD). A voucher sample (\#18350) was deposited at the Herbarium Vale do São Francisco (HVASF) of the Federal University of San Francisco Valley. All procedures for access to genetic patrimony and associated traditional knowledge were carried out, and the project was registered in SisGen (Register \# A4AB302).

\section{Preparation of the plant extract}

The dried and pulverized leaves (1400 g) were macerated with ethanol $95 \%$ (2 L) at room temperature for $72 \mathrm{~h}$. The extractive solution was filtered and concentrated under reduced pressure in a rotatory evaporator at $50^{\circ} \mathrm{C}$, producing $600 \mathrm{~g}$ of crude ethanolic extract of $A$. vepretorum (Av-EtOH).

\section{HPLC-diode array detection analysis of phenolic compounds}

The chromatographic analyses were performed on an HPLC from Shimadzu with a DAD and a C18 column with dimensions of $250 \times 4.6 \mathrm{~mm}, 5 \mu \mathrm{m}$ (ThermoScientific Hypersil) with a guard column. The temperature was kept stable at $30^{\circ} \mathrm{C}$ throughout the whole analysis. 2 solutions were used as the mobile phase: Solution A consisted of ultrapurified water + trifluoroacetic acid $0.01 \%$ $(\mathrm{v} / \mathrm{v})$ and $\mathrm{B}$, acetonitrile solution. Samples were analyzed using a gradient system described in > Table 7 , with a $0.8 \mathrm{~mL} / \mathrm{min}$ flow. The analytical standards and samples were injected in the volume of $5 \mu \mathrm{L}$ and the detection was performed in DAD at a wavelength of 
- Table 7 Gradient system used in the analysis with HPLC-DAD.

\begin{tabular}{|l|l|l|l|}
\hline & $\begin{array}{l}\text { Time } \\
\text { (min) }\end{array}$ & $\begin{array}{l}\text { Solution A } \\
(\mathbf{\%})\end{array}$ & $\begin{array}{l}\text { Solution B } \\
\mathbf{( \% )}\end{array}$ \\
\hline Linear gradient & $0-40$ & $100-60$ & $0-40$ \\
\hline Isocratic & $40-50$ & 60 & 40 \\
\hline Linear gradient & $50-60$ & $60-100$ & $40-0$ \\
\hline
\end{tabular}

$340 \mathrm{~nm}$. The software LC Solution 1.0 (Shimadzu) was used for data analysis.

\section{Animals}

Male and female adult albino Swiss mice (30-40 g) were used in this study. The animals were randomly housed in plastic cages at $22 \pm$ $2{ }^{\circ} \mathrm{C}$ on a 12 -h light/dark cycle with free access to food and water. All experiments were approved by the Federal University of San Francisco Valley Animal Care and Use Committee (No. 0004/261011).

\section{Acute toxicity studies}

Healthy Swiss mice of either sex were divided into groups of 10 animals ( 5 males and 5 females). All animals had free access to water and food, except for a period ( $12 \mathrm{~h}$ ) before oral administration of single doses of the extract (Av-EtOH). In the experimental group, a single dose of $\mathrm{Av}$-EtOH $1 \mathrm{~g} / \mathrm{kg}$ was administered, and the control group received saline, all orally by gavage. The animals were observed during the first 4 and $12 \mathrm{~h}$ after treatment, and every single day, throughout 14 days for signs of toxicity and occurrence of death. Some parameters were analyzed daily for 14 days, such as the consumption of food and water and changes in body weight. Death occurrence and toxicity signs such as piloerection, palpebral ptosis, locomotion, hypothermia, muscular tonus, trembling, convulsions, and other manifestations were analyzed. At the end of the $14^{\text {th }}$ day, the animals were anesthetized with ketamine $(90 \mathrm{mg} / \mathrm{kg}$, i.p.) and xylazine ( $5 \mathrm{mg} / \mathrm{kg}$, i.p.), and blood was collected by cardiac puncture. Selected organs (lungs, heart, stomach, spleen, pancreas, ovaries, testicles, liver, and kidneys) were carefully dissected and weighed, and a macroscopic analysis was performed.

\section{Subacute toxicity studies}

Healthy mice of either sex were divided into groups of 3 ( 5 males and 5 females) under the same conditions as described previously. The Av-EtOH extract was administered orally daily for 30 days at doses of 100 and $400 \mathrm{mg} / \mathrm{kg}$. These doses were chosen based on the doses administered in previous pharmacological studies performed by our research group with this species [4-7]. The control group received saline. Death and signs of toxicity were observed daily. At the end of the 30-day period, the animals were anesthetized and the blood and organs were collected as described above.

\section{Behavioral analysis}

To perform the behavioral analysis, specific parameters (piloerection, palpebral ptosis, abdominal contortions, convulsions, catatonia, tremors, frontal paws paralysis, sedation, increased ambulation, decreased touch response, intense vibrissae movement, aggressiveness, and stereotypy) were assessed after administration of $\mathrm{Av}-\mathrm{EtOH}$. On the first day, these parameters were evaluated at times $0.5,1,2,3$, and $4 \mathrm{~h}$ after the administration of the extract. On the other days, the behavioral evaluation was done daily until the last day of subchronic toxicity [23].

\section{Hematological and biochemical parameters}

Blood was removed by cardiac puncture for analysis of the hematological parameters red blood cell count $\left(10^{6}\right.$ cells $\left./ \mathrm{mm}^{3}\right)$, hemoglobin $(\mathrm{g} / \mathrm{dL})$, hematocrit $(\%)$, mean corpuscular volume $\left(\mathrm{MCV}, \mu^{3}\right)$, mean corpuscular hemoglobin $(\mathrm{MCH}, \mathrm{g})$, hemoglobin concentration, mean corpuscular (MCHC, \%), leukocytes $\left(10^{3} / \mathrm{mm}^{3}\right)$, and platelets $\left(10^{3} / \mathrm{mm}^{3}\right)$, and were counted in a Horiba ABX Pentra 60 hematology analyzer. Blood smears were prepared and stained with panotic corant stain for determination of the differential counts of blood cells [24, 25].

The biochemical parameters analyzed in serum samples were glucose $(\mathrm{mg} / \mathrm{dL})$, cholesterol (mg/dL), triglycerides (mg/dL), AST/ GOT (U/L), ALT/GPT $(\mathrm{U} / \mathrm{L})$, urea $(\mathrm{mg} / \mathrm{dL})$, and creatinine $(\mathrm{mg} / \mathrm{dL})$. For the determination of the biochemical parameters, a Bioplus (BIO-200) semiautomatic analyzer was used.

\section{Macroscopic and histopathology evaluation of the organs}

After the 14 days of evaluation of acute toxicity and after 30 days of subacute toxicity, the organs were removed for macroscopic analysis. Organs (heart, lungs, liver, stomach, kidneys, pancreas, spleen, ovaries, and testicles) were collected, weighed (data not shown), and analyzed macroscopically.

Stomach, liver, and kidney tissue fragments were fixed in neutral buffered $10 \%$ formalin, dehydrated with alcohol, cleared in xylene, embedded in paraffin, sectioned $(4 \mu \mathrm{m})$ in microtome, and stained with hematoxylin and eosin. Samples were then processed and examined by optical microscopy.

\section{Statistical analysis}

The results are presented as the mean \pm standard error of the mean (SEM), and statistical significance was determined using the unpaired Student's t-test. Values were considered significantly different at $\mathrm{p}<0.05$. All analyses were performed using the GraphPad Prism 5.0 program (GraphPad Prism Software Inc.).

\section{Acknowledgments}

This work was supported by grants from the Brazilian agencies CAPES, CNPq (Process 470594/2013-6), and FACEPE. The authors wish to express their thanks to R. Mello Silva of Centro de Referência para Recuperação de Áreas Degradadas (CRAD) for the botanical identification of the plant material, and the Alpha Laboratory of Clinical Veterinary Analysis for the hematological and biochemical exams. We would also like to thank teacher Abilio Borghi for the grammar review of the manuscript.

\section{Conflict of Interest}

The authors declare no conflict of interest. 


\section{References}

[1] Maas P, Lobão A, Rainer H. Lista de Espécies da Flora do Brasil.Rio de Janeiro: 2015 Available at http://floradobrasil.jbrj.gov.br/jabot/ floradobrasil/FB117277 Accessed on 30 October 2018

[2] Costa EV, Dutra LM, PCDL Nogueira, VRDS Moraes, Salvador M], LHG Ribeiro, Gadelha FR. Essential oil from the leaves of Annona vepretorum: Chemical composition and bioactivity. Nat Prod Commun 2012; 7: 265-266

[3] Dutra LM, Bomfim LM, Rocha SLA, Nepel A, Soares MBP, Barison A, Costa EV, Bezerra DP. ent-Kaurane diterpenes from the stem bark of Annona vepretorum (Annonaceae) and cytotoxic evaluation. Bioorg Med Chem Lett 2014; 24: 3315-3320

[4] Diniz TC, Araújo CS, Silva JC, Oliveira-Júnior RG, Lima-Saraiva SRG, Quintans-Junior LJ, Nunes XP. Almeida JRGS. Phytochemical screening and central nervous system effects of ethanolic extract of Annona vepretorum (Annonaceae ) in mice. J Med Plan Res 2013; 7: 27292735

[5] Almeida JRGS, Araújo CS, Pessoa CÓ, Costa MP, Pacheco AGM. Atividade antioxidante, citotóxica e antimicrobiana de Annona vepretorum Mart. (Annonaceae). Rev Bras Frutic 2014; 36: 258-264

[6] Silva JC, Araújo CS, Lima-Saraiva SRG, Oliveira-Junior RG, Diniz TC, Wanderley CWS, Palheta-Júnior RC, Mendes RL, Guimarães AG, Quintans-Júnior LJ, Almeida JRGS. Antinociceptive and anti-inflammatory activities of the ethanolic extract of Annona vepretorum Mart. (Annonaceae) in rodents. BMC Complement Altern Med 2015; 15: 197

[7] Silva JC, LARO Macedo, Souza GR, Oliveira-Junior RG, Lima-Saraiva SRG, Lavor EM, Silva MG, Souza MTS, Bonjardim LR, Quintans-Júnior LJ, Mendes RL, Almeida JRGS. Orofacial antinociceptive effect of the ethanolic extract of Annona vepretorum Mart. (Annonaceae). Z Naturforsch C 2016; 71: 209-214

[8] Almeida RN. Psicofarmacologia - fundamentos práticos. 1. ed. Rio de Janeiro: Guanabara Koogan; 2006

[9] Jothy SL, Zakaria Z, Chen Y, Lau YL, Latha LY, Sasidharan S. Acute oral toxicity of methanolic seed extract of Cassia fistula in mice. Molecules 2011; 16: 5268-5282

[10] Valadares MC. Avaliação de toxicidade aguda: estratégias após a "era do teste $\mathrm{DL}_{50}$ ". Acute toxicity evaluation: strategies post " $\mathrm{LD}_{50}$ test era.". Rev Eletrônica Farm 2006; 3: 93-98

[11] Olson H, Betton G, Robinson D, Thomas K, Monro A, Kolaja G, Lilly P, Sanders J, Sipes G, Bracken W, Dorato M, Van Deun K, Smith P, Berger B, Heller $A$. Concordance of the toxicity of pharmaceuticals in humans and in animals. Regul Toxicol Pharmacol 2000; 32: 56-67

[12] Ping KY, Darah I. Acute and subchronic toxicity study of Euphorbia hirta L. methanol extract in rats. Biomed Res Int 2013; 2013: 1-14
[13] Silva SN, Abreu IC, Silva GFC, Ribeiro RM, Lopes AS, Cartágenes MSS, Freire SMF, Borges ACR, Borges MOR. The toxicity evaluation of Syzygium cumini leaves in rodents. Braz J Pharmacogn 2011; 22: 102-108

[14] Tofovic SP, Jackson EK. Effects of long-term caffeine consumption on renal function in spontaneously hypertensive heart failure prone rats. J Cardiovasc Pharmacol 1999; 33: 360-366

[15] Raza M, Shabanah OA, Gamal El-Din TM, Majed AA. Effect of prolonged vigabatrin treatment on hematological and biochemical parameters in plasma, liver and kidney of Swiss albino mice. Sci Pharm 2002; 70: 135-145

[16] Teo S, Stirling D, Thomas S, Hoberman A, Kiorpes A, Khetani V. A 90-day oral gavage toxicity study of $D$-methylphenidate and D,L-methylphenidate in Sprague-Dawley rats. Toxicology 2002; 179: 183-196

[17] Amenya HZ, Gathumbi PK, Mbaria JM, Thaiyah AG, Thoithi GN. Sub-acute toxicity of the chloroformic extract of Rapanea melanophloeos (L.) Mez in rats. J Ethnopharmacol 2014; 154: 593-599

[18] Rahman MF, Siddiqui MK, Jamil K. Effects of Vepacide (Azadirachta indica) on aspartate and alanine aminotransferase profiles in a subchronic study with rats. Hum Exp Toxicol 2001; 20: 243-249

[19] Patel SS, Verma S, Nayak G, Singhai AK, Ganesh N. Acute and sub-acute toxicity studies of Passiflora nepalensis in rats. Braz J Pharmacogn 2011; 21: 730-736

[20] El Hilaly ], Israili ZH, Lyoussi B. Acute and chronic toxicological studies of Ajuga iva in experimental animals. J Ethnopharmacol 2004; 91: $43-50$

[21] Lameire N, Van Biesen W, Vanholder R. Acute renal failure. Lancet 2005; 365: 417-430

[22] Okoye TC, Akah PA, Ezike AC, Okoye MO, Onyeto CA, Ndukwu F, Ohaegbulam E, Ikele L. Evaluation of the acute and sub acute toxicity of Annona senegalensis root bark extracts. Asian Pac J Trop Med 2012; 5: $277-282$

[23] Almeida RN, Falcão ACGM, Diniz RST, Quintans-Júnior L], Polari RN, Barbosa-Filho JM, Agra MF, Duarte JC, Ferreira CD, Antoniolli AR, Araújo CC. Metodologia para avaliação de plantas com atividade no Sistema Nervoso Central e alguns dados experimentais. Rev Bras Farm 1999; 80: 72-76

[24] Araújo AAS, Bonjardim LR, Mota EM, Albuquerque-Júnior RLC, Estevam CS, Cordeiro L, Seixas SRS, Batista JS, Quintans-Júnior LJ. Antinociceptive activity and toxicological study of aqueous extract of Egletes viscosa Less (Asteraceae). Rev Bras Ciências Farm 2008; 44: 707-715

[25] Vasconcelos THC, Modesto-Filho J, Diniz MFFM, Santos HB, FBA Moreira, Leitão PV. Artigo das folhas de Cissus sicyoides L. (Vitaceae). Medicina (B Aires) 2007; 17: 583-591 